\title{
DC conductivity of kaolin-based ceramics in the temperature range $20-600{ }^{\circ} \mathrm{C}$
}

\author{
VIERA TRNOVCOVÁ - Dpt. of Physics, Katholic University - viera.trnovcova@ku.sk \\ Rudolf PODOBA - Dpt. of Physics, Faculty of Civil Engineering, Slovak University of Technology \\ - rudolf.podoba@stuba.sk \\ IGOR ŠTUBŇA - Dpt. of Physics, Constantine the Philosopher University - istubna@ukf.sk
}

Received: 16. 01. 2012. • Érkezett: 2012. 01. 16. http://dx.doi.org/10.14382/epitoanyag-jsbcm.2012.8

Electrical dc conductivity of kaolin and ceramic material consisting of $50 \mathrm{wt} . \%$ of kaolin and clay, $25 \mathrm{wt} . \%$ of quartz and $25 \mathrm{wt} . \%$ of feldspar was measured in the temperature range of $20-600{ }^{\circ} \mathrm{C}$. At low temperatures $\left(20-200{ }^{\circ} \mathrm{C}\right)$, charge carriers are $\mathrm{H}^{+}$and $\mathrm{OH}^{-}$ions released from defects located on crystal surfaces and polar water molecules in the pores. In this temperature region, the conduction activation energy is $0.3-0.35 \mathrm{eV}$. Upon releasing physically bound water, up to start of dehydroxylation at temperature $\sim 450{ }^{\circ} \mathrm{C}$, dc conductivity is determined by transport of $\mathrm{Na}^{+}, \mathrm{Ca}^{2+}$ and $\mathrm{K}^{+}$ions. The conduction activation energy in this region is $1.03 \mathrm{eV}$. During dehydroxylation, the charge carriers associate into neutral complexes with $\mathrm{OH}^{-}$ions, which are released from kaolinite lattice. The result is a temporary decrease in the dc conductivity. Temperature dependences of the dc conductivity show a slight anisotropy. Conductivity is higher in the direction parallel with the basic faces of kaolinite crystals. In fired ceramics, the glassy phase has a dominant influence on the dc conductivity, which is determined by the concentration and mobility of $\mathrm{Na}^{+}$and $\mathrm{K}^{+}$ions. The conduction activation energy is $0.78 \mathrm{eV}$. Above $300^{\circ} \mathrm{C}$, fired kaolin-based ceramics can be considered fast ionic conductors.

\section{Introduction}

Ceramic materials are widely used by households and the industrial sector for a variety purposes. Properties of each final ceramic product depend on its composition and method of preparation. Understanding physical and chemical changes during manufacturing of the ceramics, such as heat treatment (drying and firing) of kaolin-based ceramics, has practical applications for industry, making it an important focus of ceramic research. Experimental studies of these processes are usually performed by thermal analysis DTA, TGA, and TDA. Analysis using temperature dependences of electrical properties is rarely used.

The main part of the kaolin-based ceramics is kaolinite. Therefore, physical properties of green ceramic bodies are mainly determined (up to $1000{ }^{\circ} \mathrm{C}$ ) by the changes which take place in kaolinite and/or metakaolinite. Two important processes take place in the temperature range $20-750^{\circ} \mathrm{C}$ :

a) Release of physically bound water is a low temperature process, which takes place at temperatures lower than $200{ }^{\circ} \mathrm{C}$, as shown in the DTA and TGA curves in Fig. 1 .

b) Release of chemically bound water is linked with dehydroxylation of kaolinite in the temperature range from 400 to $750{ }^{\circ} \mathrm{C}$ [1]. Dehydroxylation is accompanied with a significant mass loss, see TGA curve in Fig. 1.

Both these processes are endothermic as confirmed by DTA minima at $\sim 150{ }^{\circ} \mathrm{C}$ and $\sim 620^{\circ} \mathrm{C}$ in Fig. 1 . The sharp exothermic maximum at $\sim 1000{ }^{\circ} \mathrm{C}$, see Fig. 1, belongs to a transformation of metakaolinite into spinel and mullite.

Electrical dc and ac conductivities of kaolin and kaolinbased ceramics were studied in [1-9] during the heating and cooling regimes, up to $600{ }^{\circ} \mathrm{C}$. A short review of the results and conclusions concerning the dc conductivity of kaolin and vacuum extruded ceramic samples is the main topic of this review article.
Viera TRNOVCOVÁ

Graduated from Faculty of Electrical Engineering (1958). Then she worked at the Institute of Physics of the Slovak Academy of Sciences (1959-2000) where she obtained a PhD (CSc) degree (1969) from research on defect interaction, diffusion mechanisms, electrical and dielectrical properties of ionic crystals. Later she works as a leading researcher at Faculty of Materials Science and Technology of Slovak University of Technology, and, in the present, for Catholic University in Ružomberok. A field of research: structure and electrical and dielectrical properties of ionic crystals, ceramics, composites, and glasses.

Rudolf PODOBA Graduated from Constantine the Philosopher University (2009), major Physics of Materials. In the present, he is a PhD student and assistant professor at Faculty of Civil Engineering of Slovak University of Technology. A field of research: building ceramics, raw materials, thermal analyses.

Igor ŠTUBŇA

Graduated from Sankt Peterburg Electrotechnical University (1965), major Electrophysics semiconductors and dielectrics. PhD (CSc) degree he earned in Institute of Physics of the Slovak Academy of Sciences (Mechanica properties of electroceramics during dehydroxylation) in 1980. In the present, he is an associate professor at the Physics department of Constantine the Philosopher University. A field of research: mechanical and thermophysical properties of electroceramics and building ceramics.

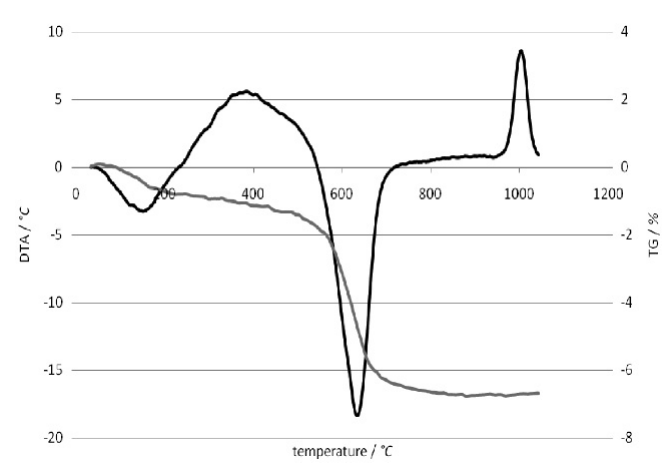

Fig. 1. DTA curve (black line) and TG curve (gray line) of quartz porcelain [1] 1. ábra A kvarc-porcelán DTA (fekete) és TG (szürke) görbéje [1] szerint

\section{Experimental}

For dc conductivity measurements, samples of a cylindrical shape were used. The samples were prepared from a plastic mass containing $20 \%$ of water by the laboratory extruder. After free air-drying, the samples had a radius of $11.5 \mathrm{~mm}$ and thickness of $2.5 \mathrm{~mm}$ up to $3.0 \mathrm{~mm}$. The samples were prepared from a mixture of minerals used for manufacturing high voltage insulators. The composition of green samples was

a) $50 \mathrm{wt} . \%$ of kaolin and clay, $25 \mathrm{wt} . \%$ of quartz and 25 wt. $\%$ of feldspar,

b) $100 \mathrm{wt}$ \% of kaolin.

Before electrical measurements, samples were heated with infrared bulb for $30 \mathrm{~min}$ at $60-80{ }^{\circ} \mathrm{C}$ to remove physically bound water. Then colloidal graphite electrodes were deposited 
onto both bases of the sample. Afterwards, samples were shortly heated with an infrared bulb to dry colloidal graphite and prevent its penetration into the sample.

Measurement of the dc conductivity was performed using the volt-ampere method, where the dc source of voltage, dynamic electrometer RFT, VA-J-51 (Germany), and the sample create a simple serial circuit. The sample was located in a vertical furnace with a kanthal wire heating element fed from a temperature programmer which controlled the heating with a rate of $2.5^{\circ} \mathrm{C} / \mathrm{min}$ or $5{ }^{\circ} \mathrm{C} / \mathrm{min}$. Platinum electrodes were pressed against the sample with a helical spring to gain a reliable electrical contact. The maximum working temperature was $\sim 600{ }^{\circ} \mathrm{C}$. Temperature was measured with the chromelalumel (type $\mathrm{K}$ ) thermocouple. The disadvantage of graphite electrodes is their oxidation at temperatures above $400{ }^{\circ} \mathrm{C}$ according to equation $\mathrm{C}(\mathrm{s})+\mathrm{O}_{2}(\mathrm{~g}) \rightarrow \mathrm{CO}_{2}(\mathrm{~g})$. To avoid this, measurements in the vacuum of $0.1 \mathrm{~Pa}$ were performed.

\section{Results and discussion}

\subsection{The dc conductivity of kaolin}

The dc conductivity of kaolin was measured in $[1,2,4]$. Two mechanisms of the dc electrical conductivity with slightly different activation energies were identified in the temperature range from $150{ }^{\circ} \mathrm{C}$ to $400^{\circ} \mathrm{C}$. Dc measurements during repeated heating and cooling cycles give results not significantly different from results obtained in the first measurement, Fig. 2.

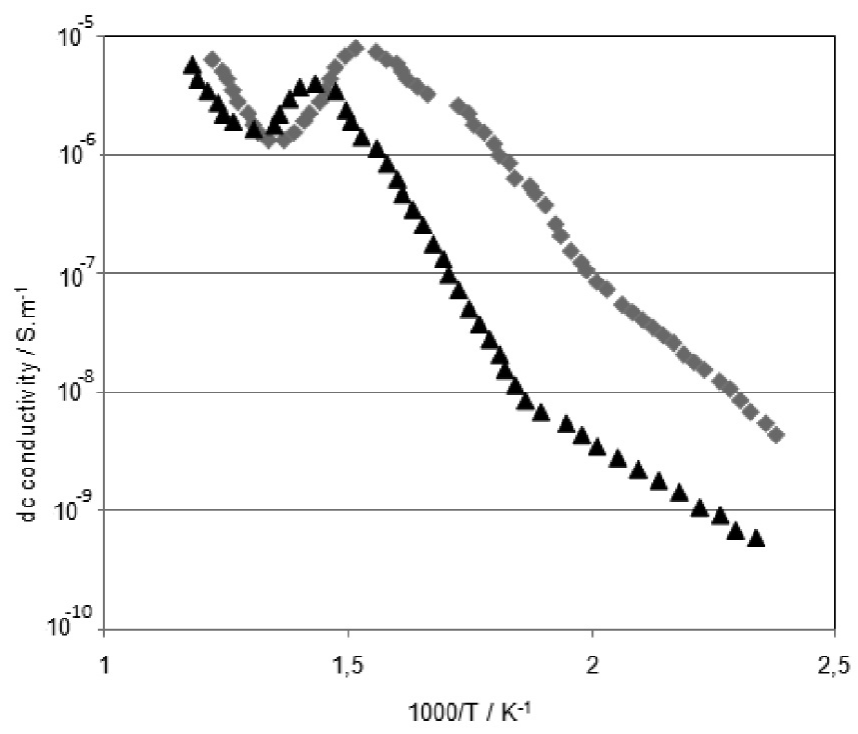

Fig. 2. Temperature dependence of the dc conductivity of Sedlec kaolin (gray points), and Podborany kaolin (black points)

2. ábra A sedleci (szürke) és a podborányi (fekete) kaolin DC vezetési tényezöje a hömérséklet függvényében

An increase in the dc electrical conductivity at temperatures lower than $260{ }^{\circ} \mathrm{C}$ can be explained by superposition of deliberation of residual physically bound water (transport of $\mathrm{H}^{+}$and $\mathrm{OH}^{-}$ions) and by migration of $\mathrm{Ca}^{2+}, \mathrm{Na}^{+}$and $\mathrm{K}^{+}$ions. Above this temperature, up to the temperature of the onset of the dehydroxylation, an increase in conductivity is caused by migration of $\mathrm{Ca}^{2+}, \mathrm{Na}^{+}$and $\mathrm{K}^{+}$ions. Their mobility increases with increasing temperature. During dehydroxylation, two processes take place. The first process is a removal of $\mathrm{OH}^{-}$ groups from the kaolinite lattice which could increase the values of the measured dc conductivity. However, part of these ions associates with $\mathrm{Na}^{+}, \mathrm{Ca}^{2+}$ and $\mathrm{K}^{+}$ions, creating dipoles that do not contribute to the $\mathrm{dc}$ conductivity. This mechanism causes a temporary decrease in the dc conductivity. The second process is a reaction between deliberated $\mathrm{OH}^{-}$groups according to equation $\mathrm{OH}^{-}+\mathrm{OH}^{-} \rightarrow \mathrm{H}_{2} \mathrm{O}+\mathrm{O}^{2-}[10]$. This reaction decreases the number of $\mathrm{OH}^{-}$charge carriers. A temporary decrease in the $\mathrm{dc}$ conductivity is observed in the region of dehydroxylation. After its completion, an increase in the dc conductivity occurs as a consequence of the previously mentioned ion migration.

\subsection{The dc conductivity of green quartz porcelain}

Results of dc measurement performed on the sample with a green composition $50 \mathrm{wt}$.\% of kaolin and clay, $25 \mathrm{wt} . \%$ of quartz and $25 \mathrm{wt} . \%$ of feldspar are published in [8]. According to the results shown as black points in Fig. 3, physically bound water is released at temperatures lower than $150{ }^{\circ} \mathrm{C}$, which causes an almost stable conductivity $\sim 10^{-13} \mathrm{~S} / \mathrm{m}$ from room temperature up to $150{ }^{\circ} \mathrm{C}$, at the first measurement. The charge carriers are $\mathrm{H}^{+}$and $\mathrm{OH}^{-}$ions released from defects located on the crystal surfaces and polar water molecules in the pores.

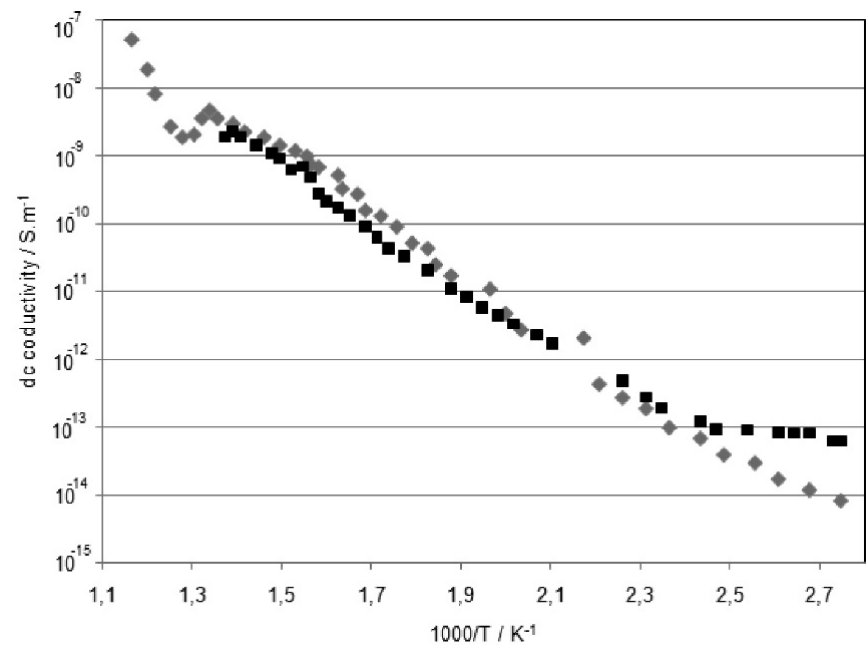

Fig. 3. Temperature dependence of $d c$ conductivity of the green quartz porcelain sample. The first measurement after preheating at $110^{\circ} \mathrm{C}-$ (black points), and repeated measurement - (gray points)

3. ábra Nyers kvarc-porcelán minta DC vezetési tényezöje $110^{\circ} \mathrm{C}$-nál. Az elsö (fekete) és a megismételt (szürke) mérés eredményei

Above the temperature $150{ }^{\circ} \mathrm{C}$, the $\mathrm{dc}$ conductivity is determined by motion of $\mathrm{Na}^{+}, \mathrm{Ca}^{2+}$ and $\mathrm{K}^{+}$ions. This process imitates Arrhenius-like temperature dependence with conduction activation energy of $1.03 \mathrm{eV}$, up to the start of dehydroxylation at the temperature $\sim 450{ }^{\circ} \mathrm{C}$. At the first measurement, heating and measurement were stopped before the onset of dehydroxylation.

After the first heating, the sample was subjected to a repeated heating, see gray points in Fig. 3. The character of low-temperature conductivity is different compared to the first heating; values of the dc conductivity at low temperatures are smaller. As $\mathrm{H}^{+}$and $\mathrm{OH}^{-}$ions were mostly eliminated during the first heating, the conductivity results from motion of the $\mathrm{Na}^{+}$, 
$\mathrm{Ca}^{2+}$ and $\mathrm{K}^{+}$charge carriers. The presence of these cations was confirmed by a chemical analysis.

In the dehydroxylation region, $\mathrm{OH}^{-}$ions released from kaolinite lattice are also charge carriers. Between these ions, the reaction $\mathrm{OH}^{-}+\mathrm{OH}^{-} \rightarrow \mathrm{H}_{2} \mathrm{O}+\mathrm{O}^{2-}$ takes place, leading to a decrease in the concentration of $\mathrm{OH}^{-}$ions. Part of these ions associates with $\mathrm{Na}^{+}, \mathrm{Ca}^{2+}$, and $\mathrm{K}^{+}$ions, creating dipoles that do not contribute to the dc conductivity. Both mechanisms cause a temporary decrease in the dc conductivity.

\subsection{Influence of the texture on conductivity}

Recent studies have shown that anisometric thin kaolinite crystals, which represent the main part of unfired ceramics, get arranged upon extruding in a vacuum press, i.e. a technological texture is created [11-13]. The most pronounced texture is located in the surface layer of the blank, so the samples were taken from this place. Two kinds of the samples were prepared: 1) samples with the current density vector parallel to the axis of the blank (i.e. parallel to the direction of extruding), referred to as "samples with A-texture", 2) samples with the current density vector parallel to the radius of the blank, referred to as "samples with R-texture". The texture was detected using X-ray diffraction (powder diffractometer Philips, $\mathrm{CuK}_{\alpha}$ radiation) [9]. The differences between the XRD patterns clearly confirm that thin quasi-hexagonal kaolinite platelets are predominantly perpendicular to the radius of the blank. These results are in a full agreement with the results obtained in $[11,13,14]$. The authors of $[7,9]$ have also observed that feldspar crystals are partially oriented and the quartz crystals are randomly oriented. Upon heating up to $600^{\circ} \mathrm{C}$, a dehydroxylation of samples with R-texture was completed. However, samples with A-texture contained some remains of kaolinite even after this thermal treatment. Therefore, retardation of the process of dehydroxylation in samples with the A-texture was confirmed [12]. We expect that dehydroxylation does not influence the occurrence of the technological texture. Actually, upon dehydroxylation, the shape of metakaolinite crystals is the same as that of initial kaolinite crystals because the dehydroxylation process takes place within kaolinite crystals $[15,16]$. A conservation of the technological texture in dehydroxylated samples is implied also by the well preserved anisotropy of feldspar diffraction peaks (Fig. 4). Electron scanning microscopy proved that oriented anisometric pores contribute to both formation and conservation of the texture [13].

Results of the dc conductivity measurement in the textured dehydroxylated samples are presented in Fig. 5. The dc conductivity depends on concentration and mobility of delocalized $\mathrm{H}^{+}, \mathrm{Na}^{+}, \mathrm{K}^{+}$and $\mathrm{OH}^{-}$ions. Temperature dependence of the dc conductivity shows a significant anisotropy for both "as received” [9] samples and dehydroxylated ones (Fig. 5). This is understandable because the kaolinite and metakaolinite crystals have the same shape. The dc conductivity of the samples with the A-texture is higher than that of the samples with the R-texture over the whole temperature range of $20-600{ }^{\circ} \mathrm{C}$. To avoid the effect of an unlike initial physically bounded water content in the samples, the samples were preheated at $150{ }^{\circ} \mathrm{C}$ before the conductivity measurement.
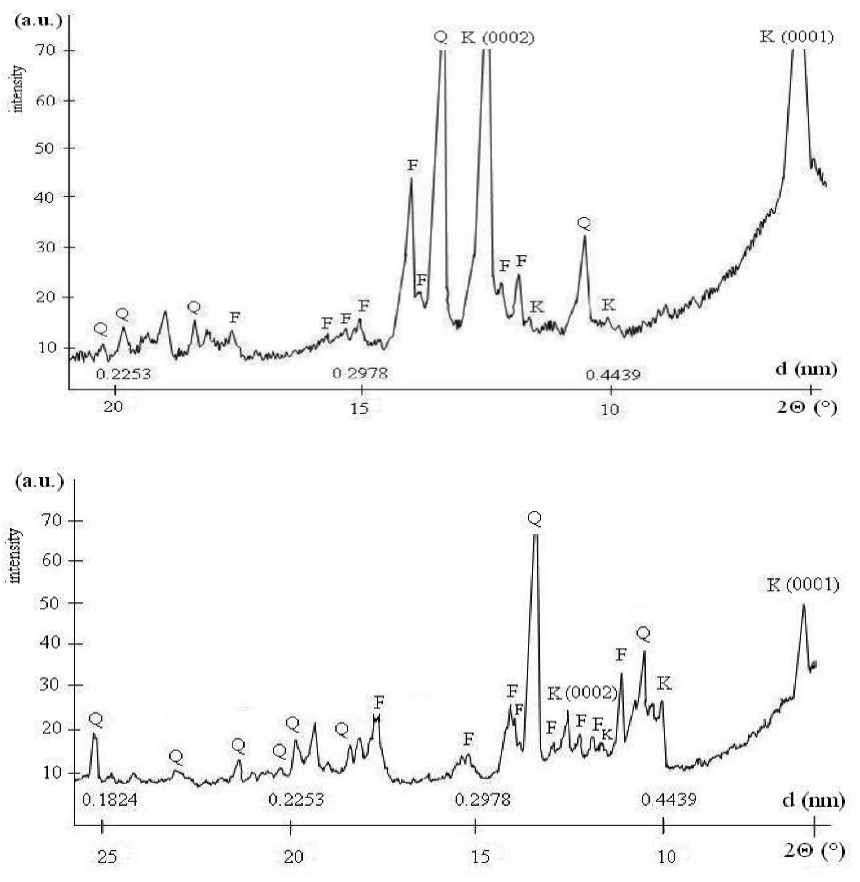

Fig. 4. X-ray diffraction patterns of vacuum extruded ceramics with R-texture (upper picture), and A-texture (lower picture), where Q: quartz, F: feldspar, K: kaolinite

4. ábra AzR (felső kép) és az A (alsó kép) anyagszerkezetü, vákuumextrudált kerámiák röntgenképe, ahol Q: kvarc, F: földpát és K: kaolin

Temperature dependences of the dc conductivity can be broken down into three sections (Fig. 5). The section between 20 and $150{ }^{\circ} \mathrm{C}$, with conduction activation energy $E_{a}=0.3-$ $0.35 \mathrm{eV}$, has protons as dominant charge carriers. At higher temperatures, $150-420^{\circ} \mathrm{C}$, with conduction activation energy $E_{\sigma}=0.98 \mathrm{eV}$, the dominant charge carriers are $\mathrm{Na}^{+}$and $\mathrm{K}^{+}$ions. These conduction activation energies are almost independent on the texture.

During dehydroxylation, over $420^{\circ} \mathrm{C}$, removal of the constituent water is accompanied with a temporary decrease of the $\mathrm{dc}$ conductivity for A-texture. The same result was obtained from the dc conductivity measurements of kaolin samples during dehydroxylation $[1,4]$. This decrease of conductivity was not observed in temperature dependences of the ac conductivity $[7,9]$. Therefore, we suppose that an association of free $\mathrm{Na}^{+}$and $\mathrm{K}^{+}$ions with liberated $\mathrm{OH}^{-}$ions into dipole complexes takes place during dehydroxylation. These complexes do not contribute to the dc conductivity but they contribute to the ac conductivity due to a dielectric relaxation. The association process starts probably at lower temperatures because in this temperature range long-term annealing of samples decreases the dc conductivity. In samples with the A-texture, the temperature at the onset of this decrease is higher, and the process of dehydroxylation is completed at a higher temperature than in samples with the R-texture (Fig. 5). It confirms that the R-texture accelerates the process of dehydroxylation, analogously to an acceleration of the process of the physically bounded water removal by this texture. In dehydroxylated samples (using a linear heating up to $600^{\circ} \mathrm{C}$ ), the conduction activation energy increases and reaches values of $1.11-1.17 \mathrm{eV}$. However, the conductivity is changed only slightly, and the anisotropy of the conductivity remains. 


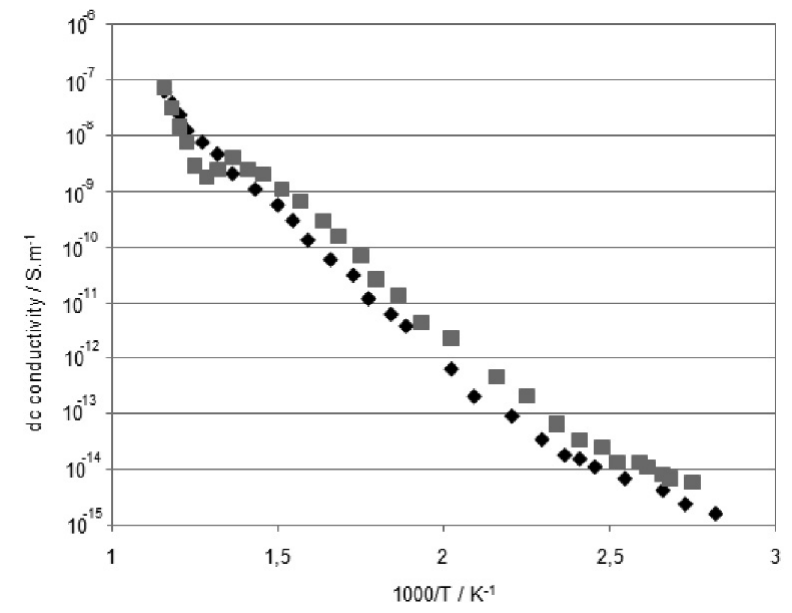

Fig. 5. The temperature dependence of the dc conductivity of vacuum extruded dehydroxylated samples with R-texture (black points) and A-texture (gray points)

5. ábra AzR (fekete) és az A (szürke) anyagszerkezetü, vákuumextrudált kerámia próbatestek DC vezetési tényezője a hőmérséklet függvényében

During high temperature sintering, a new multiphase system is created. The main part of the system is a glassy phase (about $65 \%)$. This phase has a dominant influence on electrical and dielectric properties of fired ceramics $[15,17]$. These properties are determined by the concentration and mobility of $\mathrm{Na}^{+}$and $\mathrm{K}^{+}$ions in this phase. In the whole temperature range, the temperature dependence of the $\mathrm{dc}$ conductivity of the fired samples shows a unique migration mechanism with activation energy of $0.78 \mathrm{eV}$. After firing, the dc conductivity increases about $10^{4}$ times $[9,7]$. Enhancement of the dc conductivity is more pronounced for a longer firing [15]. Therefore, above $300{ }^{\circ} \mathrm{C}$, the investigated fired ceramics can be considered fast ionic conductors.

\section{Conclusion}

Measurement of the dc conductivity is an effective tool in the experimental study of kaolin and kaolin-based ceramics. It was found:

- Charge carriers at low temperatures $\left(20-200^{\circ} \mathrm{C}\right)$ are mainly ions $\mathrm{H}^{+}$and $\mathrm{OH}^{-}$ions released from defects located on the crystal surfaces and polar water molecules in the pores. The conduction activation energy of the $\mathrm{dc}$ conductivity is $0.3-0.35 \mathrm{eV}$.

- After completion of the release of the physically bound water, electrical conductivity is determined by motion of the $\mathrm{Na}^{+}, \mathrm{Ca}^{2+}$ and $\mathrm{K}^{+}$ions. This process is consistent with Arrhenius-like temperature dependence of the dc conductivity with conduction activation energy of $1.03 \mathrm{eV}$, up to the start of dehydroxylation at the temperature $\sim 450{ }^{\circ} \mathrm{C}$.

- During dehydroxylation, ions $\mathrm{OH}^{-}$are released from the kaolinite lattice. Between these ions, a reaction $\mathrm{OH}^{-}$ $+\mathrm{OH}^{-} \rightarrow \mathrm{H}_{2} \mathrm{O}+\mathrm{O}^{2-}$ leads to lowering of the concentration of $\mathrm{OH}^{-}$ions. Some part of these ions combines with $\mathrm{Na}^{+}, \mathrm{Ca}^{2+}$ and $\mathrm{K}^{+}$creating dipoles which do not contribute to the dc conductivity. Both mechanisms cause a temporary lowering of the dc conductivity.
- Temperature dependences of the dc conductivity show a slight anisotropy due to the occurrence of technological texture. The texture is created mainly near the outer surface of the wet ceramic blank during extruding. The dc conductivity is higher in the direction parallel with the basic faces of the kaolinite crystals than in the direction perpendicular to these faces.

- During the high temperature sintering, a new multiphase system is created with a significant part of the glassy phase (about $65 \%$ ). This phase has a dominant influence on the dc conductivity, which is determined by the concentration and mobility of $\mathrm{Na}^{+}$and $\mathrm{K}^{+}$ions in this phase. Activation energy of the dc conductivity is $0.78 \mathrm{eV}$. Above $300^{\circ} \mathrm{C}$, the fired kaolin-based ceramics can be considered as fast ionic conductors.

\section{References}

[1] Riedlmajer R. - Štubňa I. - Varga G.: Termoelektrická a termodilatometrická analýza anglických kaolínov. Silika, 2006, 119 - 121

[2] Štubňa I. - Kozík T.: Elektrická vodivost kaolínov v intervale teplôt 150-560 ${ }^{\circ} \mathrm{C}$, XIII. konferencia TERMANAL, Stará Lesná 1994, 120-121

[3] Kozík T. - Štubňa I. - Mariani E.: Vplyv lisovacieho tlaku na teplotnú závislost' elektrickej vodivosti keramického materiálu, IX. Konferencia TERMANAL, Vysoké Tatry 1982, 141 -142

[4] Štubňa I. - Kozík T.: Electric conductivity of kaolin in the temperature range 150-560 ${ }^{\circ}$ C. Journal of Thermal Analysis, 46, 1996, $607-610$

[5] Kozík T. - Kalužný J. - Štubňa I. - Riedlmajer R.: Elektrické vlastnosti a ich vztah k režimu výpalu technického porcelánu. In: Zb. konf. Výpal keramiky '97, Karlovy Vary 1997, 75 - 80

[6] Trnovcová, V. - Kozík, T. - Mariani, E. - Štubňa, I.: Relaxácia elektrických vlastností elektroporcelánovej zmesi v teplotnom rozsahu 20-250 ${ }^{\circ} \mathrm{C}$. Silikáty, 32, 1988, 233-240

[7] Trnovcová V. - Kalužná M. - Furár I. - Hanic F. - Filanová J.: Influence of technological texture on electrical properties of porcelain insulators. In: $13^{\text {th }}$ Int. Scientific Conf. CO-MAT-TECH, MTF STU, Trnava 2005, 2-11

[8] Kozík, T. - Trnovcová, V. - Mariani, E. - Štubňa, I. - Roháč, J.: The temperature dependence of the electric conductivity of unfired porcelain mixture. Ceramics-Silikáty, 36, 1992, $69-72$

[9] Trnovcová, V. - Furár, I. - Hanic, F.: Influence of technological texture on electrical properties of industrial ceramics. J. Physics and Chemistry of Solids, 68, 2007, 1135-1139

[10] Drebushchak, V.A. - Mylnikova, L.N. - Drebushchak, T.N.: The mass-loss diagram for the ancient ceramics. J. Thermal Analysis and Calorimetry, 104, 2011, 459-466

[11] Kalužná, M. - Vozár, L. - Gembarovič, J. - Kaprálik, I.: The effect of texture on the thermal diffusivity of ceramic material. Ceramics-Silikáty, 36, 1992, 15-19

[12] Lučininova, N.I. et al.: Investigation of texture of the ceramic blank by thermographic methods. Steklo i keramika, 1979, N12, 16-18

[13] Kalužná, M. - Kaprálik, I. - Štubňa, I.: Závislost rýchlosti ultrazvukového vlnenia $v$ keramickom materiáli od textúry a teploty výpalu. Sklář a keramik, 37, 1987, 291-294

[14] Štubňa, I.: Vplyv textúry na mechanické a termofyzikálne vlastnosti vákuovo lisovanej elektrokeramiky. Skláŕ a keramik, 49, 1999, 197-202

[15] Wang, X. - Xiao P.: Characterisation of clay sintering process using impedance spectroscopy. J. Europ. Ceram. Soc., 22, 2002, 471-478

[16] Štubňa, I. - Varga, G. - Trník, A.: Investigation of kaolinite dehydroxylation is still interesting. Építőanyag, 58, 2006, 6-9

[17] Štubňa, I. - Trnovcová, V.: The effect of texture on thermal expansion of extruded ceramics. Ceramics - Silikáty, 42, 1998, 21-24

Ref.: http://dx.doi.org/10.14382/epitoanyag-jsbcm.2012.8 Viera Trnovcová - Rudolf Podoba - Igor Štubňa: DC conductivity of kaolin-based ceramics in the temperature range $20-600{ }^{\circ} \mathrm{C}$. Építőanyag, 64. évf. 3-4. szám (2012), 46-49. p. 